\title{
A Refinement of the Crystal Structure of $\mathrm{Na}_{2} \mathrm{CO}_{3} \cdot \mathrm{H}_{2} \mathrm{O}$
}

\author{
B. Dickens, F. A. Maver, and W. E. Brown* \\ Institute for Materials Research, National Bureau of Standards \\ Washington, D.C. 20234
}

(January 28, 1970)

\begin{abstract}
The crystal structure of synthetic $\mathrm{Na}_{2} \mathrm{CO}_{3} \cdot \mathrm{H}_{2} \mathrm{O}$ has been refined using 1231 unique $\mathrm{x}$-ray diffraction data collected by the peak height method on a diffractometer. $R=0.034$. The unit cell is $a=6.474(2), b=10.724(3)$ and $c=5.259(2) \AA$ with $z=4$ and space group $\mathrm{P} 2{ }_{1}$ ab. The calculated density is the same as the observed density, $2.26 \mathrm{~g} \cdot \mathrm{cm}^{-3}$. The structure contains sheets of $\mathrm{CO}_{3}^{2-}$ ions bonded to $\mathrm{Na}^{+}$ions and water molecules roughly halfway between the sheets. Each $\mathrm{CO}_{3}^{2-}$ bonds edgewise to both $\mathrm{Na}^{+}$ions. The $\mathrm{Na}^{+}$ions have irregular but similar coordinations of seven rieighbors. Each water molecule is bonded to both $\mathrm{Na}^{+}$ions and forms hydrogen bonds to both neighboring $\mathrm{CO}_{3}^{2-}$ layers.
\end{abstract}

Key words: Crystal structure; hydrated carbonates; hydrogen bonding; sodium carbonate; thermonatrite; $x$-ray diffraction.

\section{Introduction}

The crystal structure of $\mathrm{Na}_{2} \mathrm{CO}_{3} \cdot \mathrm{H}_{2} \mathrm{O}$ was determined except for the hydrogen positions, by Harper [1] ${ }^{1}$ in 1936 using qualitative estimates of the $x$-ray intensities. In our program of studies on coordination in hydrated carbonates [2] and phosphates [3], we have refined Harper's structure for $\mathrm{Na}_{2} \mathrm{CO}_{3} \cdot \mathrm{H}_{2} \mathrm{O}$ using new $x$-ray data. $\mathrm{Na}_{2} \mathrm{CO}_{3} \cdot \mathrm{H}_{2} \mathrm{O}$ is the mineral thermonatrite and often occurs with $\mathrm{Na}_{2} \mathrm{CO}_{3} \cdot 10 \mathrm{H}_{2} \mathrm{O}$ (natron) and $\mathrm{Na}_{2} \mathrm{CO}_{3} \cdot \mathrm{NaHCO}_{3} \cdot 2 \mathrm{H}_{2} \mathrm{O}$ (trona) $[4,5,6]$.

\section{Determination of the Structure}

Formula: $\mathrm{Na}_{2} \mathrm{CO}_{3} \cdot \mathrm{H}_{2} \mathrm{O}$. Unit cell: Orthorhombic with $a=6.472(2) \AA, b=10.724(3) \AA, c=5.259(2) \AA$ at $24{ }^{\circ} \mathrm{C}$ as calculated from three pairs of $2 \theta$ values of axial reflections from a single crystal and observed on a diffractometer. The standard deviations of the cell parameters are in parentheses and are estimates based on experience with the technique. Cell volume: 365.1 $\AA^{3}$. Wavelength used: $0.710688 \AA($ Mo K $\alpha)$. Filter: $0.025 \mathrm{~mm}$ Nb. Space Group: P2 $2_{1}$ ab. Cell contents in formula Wts: 4. Equivalent positions: $x, y, z ; 1 / 2+x$, $-y,-z ; 1 / 2+x, 1 / 2-y, z ; x, 1 / 2+y,-z$. Reciprocal lattice extinctions: $h 0 l, h \neq 2 n ; h k 0, k \neq 2 n$. Observed density: $2.255 \mathrm{~g} \cdot \mathrm{cm}^{-3}$ [7]. Calculated density: 2.256 $\mathrm{g} \cdot \mathrm{cm}^{-3}$. Habit: Fragment from plate. Size of crystal: $\sim 0.35 \mathrm{~mm}$ max. $\sim 0.05 \mathrm{~mm}$ min. Origin: Evaporation

*Director, Research Associate Program of the American Dental Association at the National Bureau of Standards.

${ }^{1}$ Figures in brackets indicate the literature references at the end of this paper. of aqueous solution at $60^{\circ} \mathrm{C}$. Linear absorption coefficient: $4.37 \mathrm{~cm}^{-1}$. Absorption corrections: None applied. Maximum error in any intensity from absorption is $\sim 10$ percent. Number of reflections: 2189 were collected from 2 octants and merged into a unique set of 1231 of which 1132 are "observed" reflections and 99 are less than $2 \sigma$ above background and are "unobserved". Maximum $\sin \theta / \lambda$ for data: 0.904 $\AA^{-1}$. Method used to estimate data: peak height measurement [8] with a single crystal diffractometer [9] and some peak heights standardized against $\theta / 2 \theta$ scans. Scattering factors: $\mathrm{Na}, \mathrm{C}, \mathrm{O}$, for neutral atoms given in reference [10]; $\mathrm{H}$ from reference [11]. Least-squares refinements: Full-matrix, with $\Sigma\left(w|| F_{\mathrm{o}}|-| F_{\mathrm{c}} \|\right)^{2}$ minimized. Refinements include unobserved reflections for which the calculated intensities are more than $2 \sigma$ above background. Least-squares weights: 1/ $\sigma^{2}$ normalized so that maximum weight is 1 . Definitions: counts in peak $=I=P-\left(T / 2 T_{\mathrm{B}}\right)\left(B_{\mathrm{L}}+B_{\mathrm{H}}\right), \sigma(I)$ $=\left(P+\left(B_{\mathrm{L}}+B_{\mathrm{H}}\right)\left(T /\left(2 T_{\mathrm{B}}\right)\right)^{2}\right)^{1 / 2}, F=((\mathrm{AF})(\mathrm{LP})(I))^{1 / 2}$, $\sigma(F)=(\sigma(I) / 2)(\mathrm{LP} / I)^{1 / 2}$ where $P=$ counts at the peak position, $B_{\mathrm{L}}$ and $B_{\mathrm{H}}=$ background counts at lower and higher $2 \theta$ respectively, $T=$ time spent counting peak, $T_{B}=$ time spent counting each background, $\mathrm{AF}=$ attenuator $\cdot$ factor, $\mathrm{LP}=$ Lorentz polarization correction.

$$
\begin{aligned}
& R_{w}=\left(\sum\left(w\left\|F_{\mathrm{o}}|-| F_{\mathrm{c}}\right\|\right)^{2} / \sum\left(w\left|F_{\mathrm{o}}\right|\right)^{2}\right)^{1 / 2} \\
& \left.R=\left(\sum \| F_{\mathrm{o}}\right\rfloor-\mid F_{\mathrm{c}} \|\right) / \sum\left|F_{\mathrm{o}}\right| .
\end{aligned}
$$


Final $R_{w}: 0.029$. Final $R: 0.032$. Average shift/error for last cycle: 0.015. Thermal parameters: anisotropic with form

$$
\begin{array}{r}
\exp \left(-1 / 4\left(a^{* 2} B_{11} h^{2}+b^{* 2} B_{22} k^{2}+c^{* 2} B_{33} l^{2}+2 a^{*} b^{*} B_{12} h k\right.\right. \\
\left.+2 a^{*} c^{*} B_{13} h l+2 b^{*} c^{*} B_{23} k l\right) .
\end{array}
$$

The structure was refined isotropically from Harper's parameters using the x-ray 67 system [12] of computer programs to $R_{w}=0.065$; the $x$ parameter of $\mathrm{Na}(1)$ was fixed at $x=0$. The structure was refined anisotropically to $R_{w}=0.044$ and the hydrogens were found unambiguously as the two highest peaks in the difference synthesis in which the coefficients were weighted by the least squares weights. The two next highest peaks were less than $3 / 4$ as high as the peaks assigned to hydrogens and were (a) halfway between $\mathrm{C}$ and $0(3)$ in the $\mathrm{CO}_{3}$ group and (b) $0.7 \AA$ from $0(1)$ of the $\mathrm{CO}_{3}$ group. The hydrogens were included with variable positional parameters and fixed thermal parameters $\left(B_{\mathrm{H}}=1 \AA^{2}\right)$ in the final refinement to $R_{w}=0.029$. The largest correlation coefficients are $\sim 0.25$ between the scale factor and the $B_{11}$ thermal parameters of the two $\mathrm{Na}$ ions and $\sim 0.15$ between these $B_{11}$ thermal parameters. Most correlation coefficients are less than 0.05 .

The atomic parameters are given in table 1 . The observed and calculated structure factors are given in table 2. The hydrogen positions obtained from the weighted difference synthesis and from the refinements differ by $0.17 \AA$. "Calculated" hydrogen positions were derived by applying the geometry of free water $\left(\mathrm{O}-\mathrm{H}=0.958 \AA, \angle \mathrm{H}-\mathrm{O}-\mathrm{H}=104.5^{\circ}\right)$ with the constraint that the $\mathrm{O}-\mathrm{H}$. . O angles be as near to linear as possible. These hydrogen positions differ from the other positions by about $0.3 \AA$. The three sets of hydrogen positions are compared in table 3 . The distances and angles which involve hydrogen were obtained using the "calculated" hydrogen positions.

\section{Description of the Structure}

The structure (fig. 1) contains $\mathrm{CO}_{3}$ anions whose planes are almost perpendicular to $a$ and which form sheets at $x \sim 0.25$ and $x \sim 0.75$. Because the $\mathrm{C}$ atoms lie close to the planes of the $a$ glides, they form columns along $a$ at $y=0.25, z \sim 0.60$. Two adjacent $\mathrm{CO}_{3}$ groups in a column are held together by both being ionically bonded to four $\mathrm{Na}$ ions and hydrogen bonded by one water molecule. The four $\mathrm{Na}$ ions and the water molecule form a pentagon roughly halfway between the $\mathrm{CO}_{3}$ sheets. Adjacent $\mathrm{CO}_{3}$ groups in a given sheet are linked by the $\mathrm{Na}$ ions that lie above and below the sheet.

\subsection{The Carbonate Anion and Invironment}

The dimensions in the $\mathrm{CO}_{3}$ anion are given in table 4 and the environment is detailed in table 4 and figure 2. The $\mathrm{CO}_{3}$ group is nearly trigonal. As can be seen in figures 1 and $2, \mathrm{O}(2)$ is the only oxygen which is not hydrogen bonded, being instead ionically bonded to four $\mathrm{Na}$ ions. The absence of hydrogen bonding to $\mathrm{O}(2)$ may account for the observation that the $\mathrm{C}-\mathrm{O}(2)$ bond is apparently the shortest of the three. $\mathrm{O}(1)$ is coordinated to three $\mathrm{Na}$ ions and is the acceptor in the hydrogen bond $\mathrm{O}(1) \ldots \mathrm{H}(1)-\mathrm{O}(4)$ from the water molecule. $\mathrm{O}(3)$ is bonded strongly to two $\mathrm{Na}$ ions and more weakly $(2.822 \AA)$ to a third $\mathrm{Na}(2)$. $\mathrm{O}(3)$ is the acceptor in the hydrogen bond $\mathrm{O}(3) \ldots$ $\mathrm{H}(2)-\mathrm{O}(4)$ from the water molecule.

Since the planes of the $\mathrm{CO}_{3}$ groups are all essentially perpendicular to $a$, this is expected to be the direction of lowest refractive index, as was found by Harper [1]. Later workers [13, 14] apparently did not permute the refractive indexes when they permuted the unit cell axes to fit crystallographic convention.

\subsection{The Sodium Environments}

The two crystallographically distinct $\mathrm{Na}$ ions in the structure are in general positions. Their environments are shown in figure 3 and are given in table 5 .

$\mathrm{Na}(1)$ is bonded ionically to five oxygens from $\mathrm{CO}_{3}$ groups, and strongly to one water oxygen. Four of the $\mathrm{CO}_{3}$ oxygens, $\mathrm{O}(1), \mathrm{O}\left(2^{\prime}\right), \mathrm{O}(3), \mathrm{O}\left(3^{\prime}\right)$, figure 3 , define an approximate square about $\mathrm{Na}(1)$, and water oxygen $\mathrm{O}(4)$ forms the apex of a square pyramid. The fifth carbonate oxygen, $\mathrm{O}(2)$, is in the same $\mathrm{CO}_{3}$ group as $\mathrm{O}(1)$; the $\mathrm{CO}_{3}$ group is therefore coordinated edgewise to $\mathrm{Na}(1)$. The position of $\mathrm{O}(2)$ is such that the coordina-

TABLE 1. Atomic parameters of $\mathrm{Na}_{2} \mathrm{CO}_{3} \cdot \mathrm{H}_{2} \mathrm{O}$

\begin{tabular}{c|c|c|r|r|r|r|r|r|r}
\hline \hline Atom & $x$ & $y$ & $z$ & \multicolumn{1}{c|}{$B_{11}^{*}$} & $B_{22}$ & \multicolumn{1}{c|}{$B_{33}$} & \multicolumn{1}{c}{$B_{12}$} & $B_{13}$ & \multicolumn{1}{c}{$B_{23}$} \\
\hline $\mathrm{Na}(1)$ & 0.0000 & $0.1938(1)$ & $0.1398(1)$ & $1.40(3)$ & $1.54(3)$ & $1.36(3)$ & $0.17(3)$ & $0.17(3)$ & $0.08(2)$ \\
$\mathrm{Na}(2)$ & $.0651(2)$ & $.0020(1)$ & $-.3786(2)$ & $1.44(3)$ & $1.19(3)$ & $1.76(3)$ & $.31(2)$ & $.25(3)$ & $.09(3)$ \\
$\mathrm{C}$ & $-.2151(3)$ & $.2556(2)$ & $.6025(3)$ & $.45(6)$ & $1.11(6)$ & $1.17(5)$ & $-.06(5)$ & $-.05(5)$ & $-.03(5)$ \\
$\mathrm{O}(1)$ & $-.2010(3)$ & $.1381(1)$ & $.5457(3)$ & $1.56(6)$ & $0.72(5)$ & $2.72(7)$ & $.08(5)$ & $-.15(6)$ & $-.47(4)$ \\
$\mathrm{O}(2)$ & $-.2027(3)$ & $.3369(1)$ & $.4267(2)$ & $1.73(6)$ & $1.27(5)$ & $1.24(5)$ & $-.05(5)$ & $-.04(5)$ & $.47(4)$ \\
$\mathrm{O}(3)$ & $-.2398(3)$ & $.2876(1)$ & $-.1639(2)$ & $1.42(6)$ & $2.14(6)$ & $0.90(4)$ & $-.28(5)$ & $.25(4)$ & $-.32(4)$ \\
$\mathrm{O}(4)$ & $.0325(3)$ & $-.0296(1)$ & $.0683(3)$ & $1.64(7)$ & $1.43(6)$ & $1.92(6)$ & $-.21(5)$ & $-.25(5)$ & $.39(4)$ \\
\hline
\end{tabular}

Figures in parentheses are standard errors in last significant figure quoted, and were computed in the final cycle of full-matrix leastsquares refinement.

*Thermal parameters are in $\AA^{2}$. 
TABLE 2. Observed and cal cul ated structure factors for $\mathrm{Na}_{2} \mathrm{CO}_{3} \cdot \mathrm{H}_{2} \mathrm{O}$

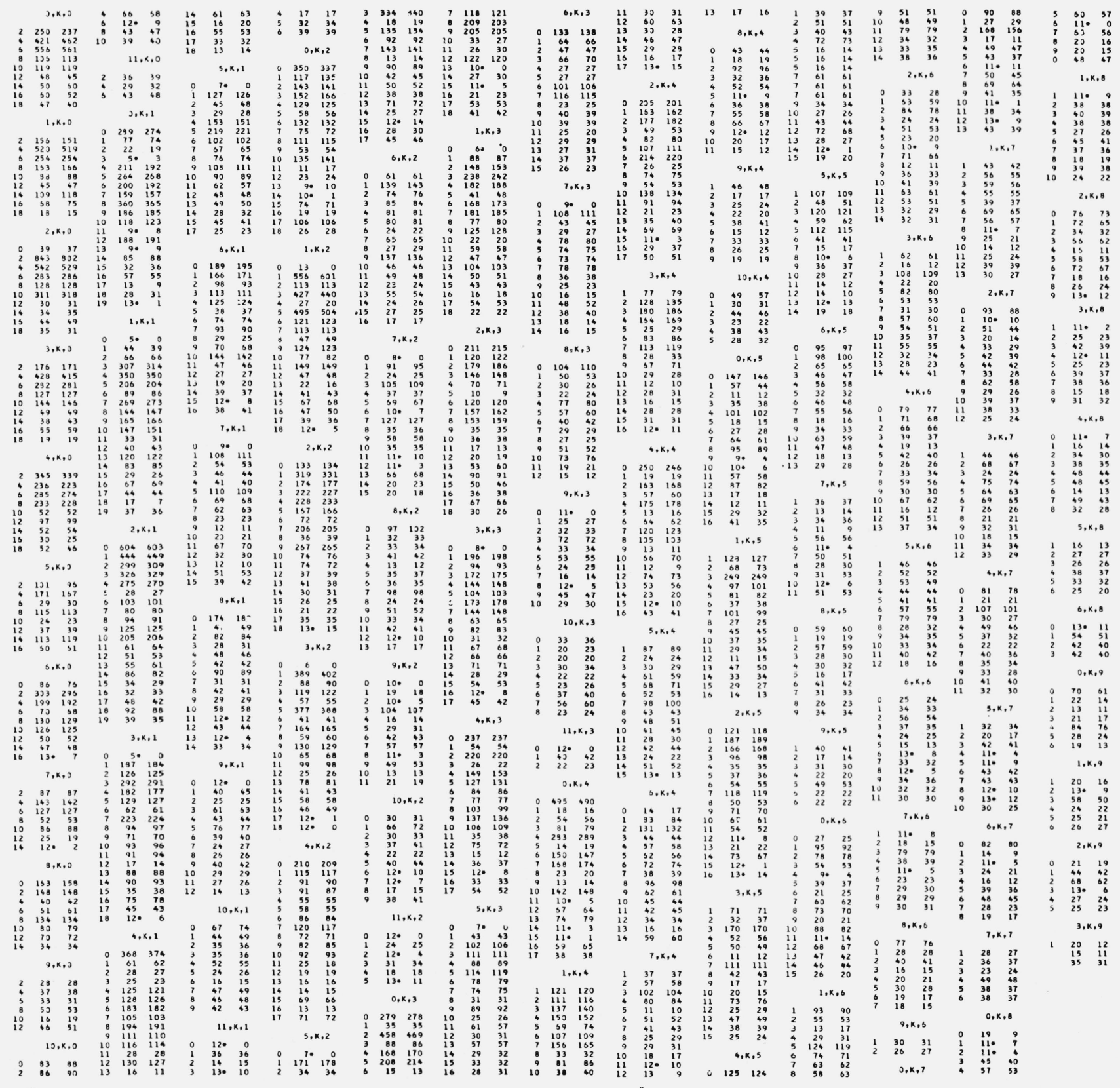

${ }^{a}$ The columns are $k_{0} 10 F_{0} \cdot 10 F_{c}$. "unobserved" reflections are marked by ". $F_{0}$ and $F_{c}$ are on an absolute scale.

TABLE 3. The hydrogen positions in $\mathrm{Na}_{2} \mathrm{CO}_{3} \cdot \mathrm{H}_{2} \mathrm{O}$

\begin{tabular}{c|c|c|c|c|c|c|c|c|c}
\hline \hline Atom & \multicolumn{3}{|c|}{$\begin{array}{c}\text { Weighted } \\
\text { difference } \\
\text { synthesis }\end{array}$} & \multicolumn{3}{c|}{$\begin{array}{c}\text { Least } \\
\text { squares } \\
\text { refinements }\end{array}$} \\
\hline & $x$ & $y$ & $z$ & $x$ & $y$ & $z$ & $x$ & $y$ & $z$ \\
$H(1)$ & 0.12 & -0.07 & 0.14 & 0.11 & -0.06 & 0.15 & 0.134 & -0.056 & 0.190 \\
$H(2)$ & -.08 & -.08 & .14 & -.10 & -.08 & .12 & -.077 & -.089 & .084 \\
\hline
\end{tabular}

*Assuming the geometry of free water with $\mathrm{O}-\mathrm{H}=0.958 \AA$ and $\angle \mathrm{H}-\mathrm{O}-\mathrm{H}=104.5^{\circ}$, and making the $\mathrm{O}-\mathrm{H}$. . . O hydrogen bonds as linear as possible. 

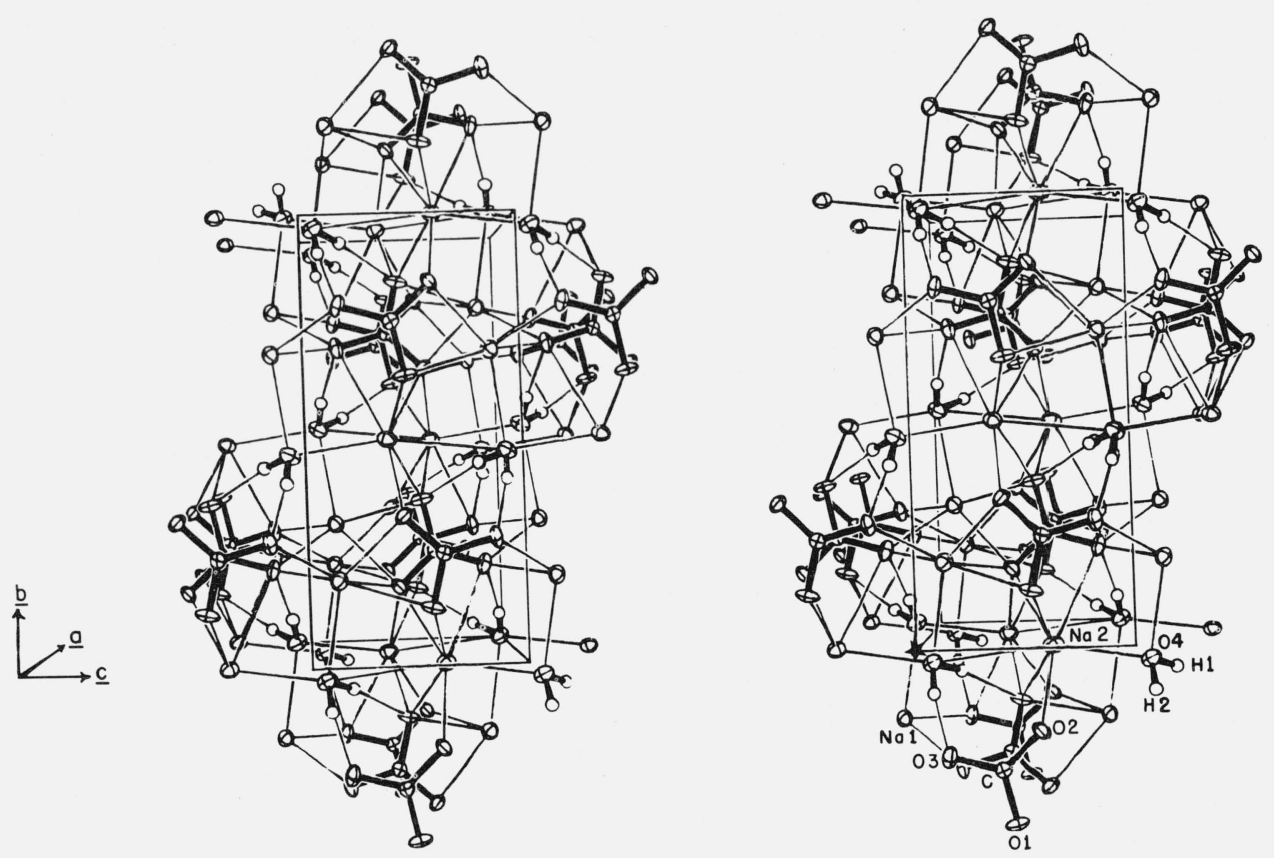

FigURE 1. A stereoscopic illustration of $\mathrm{Na}_{2} \mathrm{CO}_{3} \cdot \mathrm{H}_{2} \mathrm{O}$ viewed along a. The origin of the unit cell is marked by the asterisk.

TABLE 4. The $\mathrm{CO}_{3}$ group

\begin{tabular}{|c|c|}
\hline Atoms & $\begin{array}{l}\text { Distances, } \AA \text {, or } \\
\text { angle, deg. }\end{array}$ \\
\hline $\mathrm{C}, \mathrm{O}(1) \ldots$. & $1.299(3)$ \\
\hline $\mathrm{C}, \mathrm{O}(2) \ldots \ldots \ldots$ & $1.274(2)$ \\
\hline $\mathrm{C}, \mathrm{O}(3) \ldots \ldots$ & $1.285(2)$ \\
\hline $\mathrm{O}(1), \mathrm{O}(2) \ldots \ldots$ & $2.223(2)$ \\
\hline $\mathrm{O}(1), \mathrm{O}(3) \ldots \ldots$ & $2.229(2)$ \\
\hline $\mathrm{O}(2), \mathrm{O}(3) \ldots \ldots \ldots$ & $2.230(2)$ \\
\hline $\mathrm{O}(1), \mathrm{C}, \mathrm{O}(2) \ldots$ & 119.6(2) \\
\hline $\mathrm{O}(1), \mathrm{C}, \mathrm{O}(3) \ldots$. & $119.2(2)$ \\
\hline $\mathrm{O}(2), \mathrm{C}, \mathrm{O}(3) \ldots$. & $121.2(2)$ \\
\hline $\mathrm{O}(1), \mathrm{Na}(1) \ldots \ldots$ & $2.570(2)$ \\
\hline $\mathrm{O}(1), \mathrm{Na}(2) \ldots$. & $2.293(2)$ \\
\hline $\mathrm{O}(1), \mathrm{Na}\left(2^{\prime}\right) \ldots \ldots$ & $2.307(2)$ \\
\hline $\mathrm{O}(1), \mathrm{O}(4) \ldots \ldots$ & $2.907(2)$ \\
\hline $\mathrm{O}(1), \mathrm{H}(1) \ldots \ldots$ & 1.96 \\
\hline $\mathrm{O}(2), \mathrm{Na}(1) \ldots .$. & $2.521(2)$ \\
\hline $\mathrm{O}(2), \mathrm{Na}\left(1^{\prime}\right) \ldots$. & $2.468(2)$ \\
\hline $\mathrm{O}(2), \mathrm{Na}\left(2^{\prime}\right) \ldots$ & $2.508(2)$ \\
\hline $\mathrm{O}(2), \mathrm{Na}(2) \ldots \ldots$ & $2.491(2)$ \\
\hline $\mathrm{O}(3), \mathrm{Na}(1) \ldots \ldots$ & $2.444(2)$ \\
\hline $\mathrm{O}(3), \mathrm{Na}\left(1^{\prime}\right) \ldots \ldots$ & $2.330(2)$ \\
\hline $\mathrm{O}(3), \mathrm{Na}(2) \ldots \ldots$ & $2.822(2)$ \\
\hline $\mathrm{O}(3), \mathrm{O}(4) \ldots \ldots \ldots$ & $2.685(2)$ \\
\hline $\mathrm{O}(3), \mathrm{H}(2) \ldots \ldots$. & 1.74 \\
\hline
\end{tabular}

In all tables of interatomic distances and angles, the quantities in parentheses are standard errors in the last significant figure and were computed from the standard errors in the atomic positional parameters and in the cell parameters. The primes refer to atoms in figure 2.

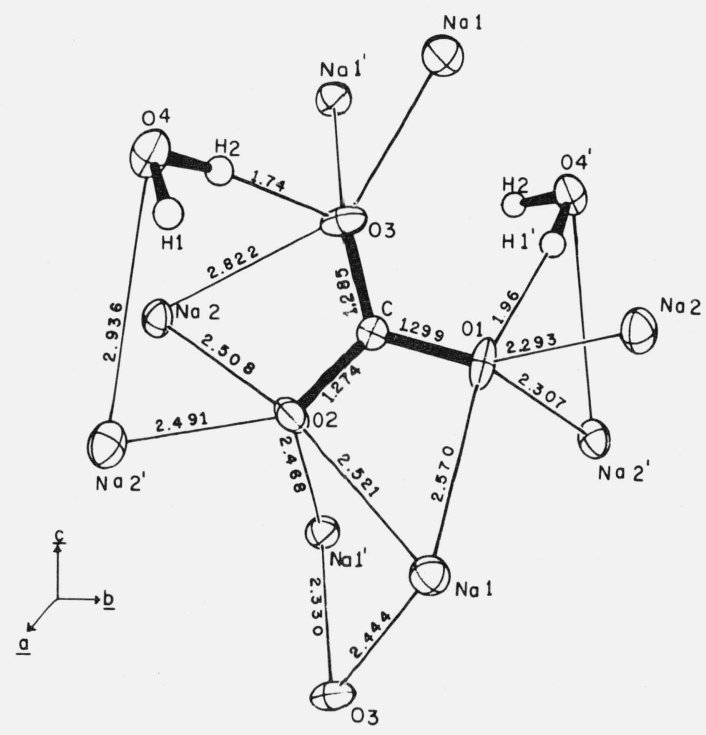

FiguRE 2. The carbonate group environment in $\mathrm{Na}_{2} \mathrm{CO}_{3} \cdot \mathrm{H}_{2} \mathrm{O}$. The primes refer to atoms in table 4.

tion about $\mathrm{Na}(1)$ cannot be considered octahedral. The next oxygen in the direction of the octahedral apex is the water oxygen $\mathrm{O}\left(4^{\prime}\right)$, which is relatively far $(3.669 \AA)$ from $\mathrm{Na}(1)$.

The coordination of $\mathrm{Na}(2)$ is similar to that of $\mathrm{Na}(1)$. $\mathrm{Na}(2)$ is slightly displaced from the center of an approximate square of carbonate oxygens, $\mathrm{O}\left(1^{\prime}\right), \mathrm{O}\left(2^{\prime \prime}\right)$, $\mathrm{O}\left(1^{\prime \prime}\right)$, $\mathrm{O}\left(2^{\prime \prime \prime}\right)$. The displacement is towards the strongly bonded water molecule $\mathrm{O}(4)$, which is the 


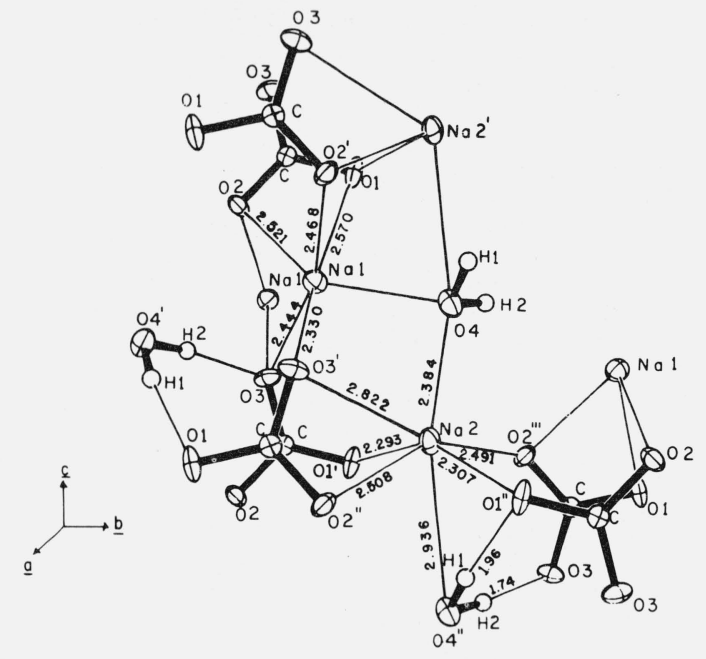

FIGURE 3. The water and sodium environments in $\mathrm{Na}_{2} \mathrm{CO}_{3} \cdot \mathrm{H}_{2} \mathrm{O}$. The primes refer to atoms in tables 5 and 6.

TABLE 5. The sodium environments

\begin{tabular}{|c|c|}
\hline Atoms & Distance, $\AA$ \\
\hline $\mathrm{Na}(1), \mathrm{O}(1) \ldots$ & $2.570(2) \AA$ \\
\hline $\mathrm{Na}(1), \mathrm{O}(2) \ldots$. & $2.521(2)$ \\
\hline $\mathrm{Na}(1), \mathrm{O}(3) \ldots$. & $2.444(2)$ \\
\hline $\mathrm{Na}(1), \mathrm{O}(4) \ldots$ & $2.434(2)$ \\
\hline $\mathrm{Na}(1), \mathrm{O}\left(2^{\prime}\right) \ldots \ldots$ & $2.468(2)$ \\
\hline $\mathrm{Na}(1), \mathrm{O}\left(3^{\prime}\right) \ldots$ & $2.330(2)$ \\
\hline $\mathrm{Na}(1), \mathrm{O}\left(4^{\prime}\right) \ldots \ldots$ & $3.669(2)$ \\
\hline $\mathrm{Na}(2), \mathrm{O}(4) \ldots$ & $2.384(2) \AA$ \\
\hline $\mathrm{Na}(2), \mathrm{O}\left(1^{\prime}\right) \ldots$ & $2.293(2)$ \\
\hline $\mathrm{Na}(2), \mathrm{O}\left(1^{\prime \prime}\right) \ldots$ & $2.307(2)$ \\
\hline $\mathrm{Na}(2), \mathrm{O}\left(2^{\prime \prime}\right) \ldots$ & $2.508(2)$ \\
\hline $\mathrm{Na}(2), \mathrm{O}\left(2^{\prime \prime \prime}\right) \ldots \ldots$ & $2.491(2)$ \\
\hline $\mathrm{Na}(2), \mathrm{O}\left(4^{\prime \prime}\right) \ldots$. & $2.936(2)$ \\
\hline $\mathrm{Na}(2), \mathrm{O}\left(3^{\prime}\right) \ldots \ldots$ & $2.822(2)$ \\
\hline
\end{tabular}

The primes refer to the atoms in figure 3 .

apex of a square based pyramid (base down in figure $3)$. The coordination of $\mathrm{Na}(2)$ is completed by $\mathrm{O}\left(4^{\prime \prime}\right)$ $(2.936 \mathrm{~A})$ which is the remaining apex of an approximate octahedron, and by $\mathrm{O}\left(3^{\prime}\right)$ which is in the same $\mathrm{CO}_{3}$ group as $\mathrm{O}\left(2^{\prime \prime}\right)$. Thus the $\mathrm{CO}_{3}$ group is coordinated edgewise to $\mathrm{Na}(2)$ also, this time using $\mathrm{O}(2)$ and $\mathrm{O}(3)$ instead of $\mathrm{O}(1)$ and $\mathrm{O}(2)$, which are used to coordinate to $\mathrm{Na}(1)$. This edgewise coordination is shown in figure 2 . The coordination to $\mathrm{Na}(2)$ comprises five carbonate oxygens and two water molecules instead of four carbonate oxygens and two water molecules as suggested by Harper [1] and noted by Wells [15].

\subsection{The Water Environment}

The water environment is given in table 6 and shown in figure 3. The water molecule is bonded to $\mathrm{Na}(1)$ and $\mathrm{Na}(2)$ with distances of 2.434 and $2.384 \AA$ respectively, and forms hydrogen bonds to oxygens $\mathrm{O}(\mathrm{l})$ and $\mathrm{O}(3)$ of neighboring $\mathrm{CO}_{3}$ groups. $\mathrm{Na}(1), \mathrm{Na}(2)$, $\mathrm{O}(1)$, and $\mathrm{O}(3)$ are arranged approximately tetrahedrally about the water oxygen. The distortion of this tetrahedron is considerable as can be seen from the angles listed in table 6 . The closest $\mathrm{H}$... Na distance is $\mathrm{H}(1) \ldots \mathrm{Na}(2)=2.42 \AA$, which is in the normal range.

TABLE 6. The water environment

\begin{tabular}{r|c}
\hline \hline \multicolumn{1}{c|}{ Atom } & $\begin{array}{c}\text { Distance } \AA \text { or } \\
\text { angle, deg. }\end{array}$ \\
\hline $\mathrm{O}(4), \mathrm{Na}(1)$ & $2.434(2) \AA$ \\
$\mathrm{O}(4), \mathrm{Na}(2)$ & $2.384(2)$ \\
$\mathrm{O}(4), \mathrm{Na}\left(2^{\prime}\right)$ & $2.936(2)$ \\
$\mathrm{O}(4), \mathrm{O}(1)$ & $2.907(2)$ \\
$\mathrm{O}(4), \mathrm{O}(3)$ & $2.684(2)$ \\
$\mathrm{H}(1), \mathrm{O}(1)$ & 1.96 \\
$\mathrm{H}(2), \mathrm{O}(3)$ & 1.74 \\
& $91.15(6)^{\circ}$ \\
$\mathrm{Na}(1), \mathrm{O}(4), \mathrm{Na}(2)$ & $109.70(7)$ \\
$\mathrm{O}(1), \mathrm{O}(4), \mathrm{Na}(1)$ & $133.83(9)$ \\
$\mathrm{O}(1), \mathrm{O}(4), \mathrm{Na}(2)$ & $129.28(9)$ \\
$\mathrm{O}(3), \mathrm{O}(4), \mathrm{Na}(1)$ & $110.29(7)$ \\
$\mathrm{O}(3), \mathrm{O}(4), \mathrm{Na}(2)$ & $88.12(6)$ \\
$\mathrm{O}(1), \mathrm{O}(4), \mathrm{O}(3)$ & 168. \\
$\mathrm{O}(4), \mathrm{H}(1), \mathrm{O}(1)$ & 167. \\
$\mathrm{O}(4), \mathrm{H}(2), \mathrm{O}(3)$ &
\end{tabular}

The prime refers to an atom in figure 3.

The calculated hydrogen positions in table 3 were obtained using the geometry of free water and imposing the condition that the $\mathrm{O}-\mathrm{H}$. . . O angles both be as linear as possible. Because $\mathrm{H}(2)$. . $\mathrm{O}(3)$ is shorter $(1.74 \AA)$ than $\mathrm{H}(1)$. . . O (1) $(1.96 \AA)$ it is possible that the hydrogen bond $\mathrm{O}(4)-\mathrm{H}(2) \ldots \mathrm{O}(3)$ is strictly linear. Assuming the same water geometry, the hydrogens would then be $\simeq 0.14 \AA$ away from the positions given in table 3 at $0.145,-0.046,0.182$ for $\mathrm{H}(1)$ and $-0.065,-0.095,0.102$ for $\mathrm{H}(2)$. The $\mathrm{O}(4)-\mathrm{H}(1) \ldots \mathrm{O}(1)$ angle would then be $156^{\circ}$, and the $\mathrm{H}(1) \ldots \mathrm{O}(1)$ and $\mathrm{H}(2) \ldots \mathrm{O}(3)$ distances would be $2.01 \AA$ and $1.73 \AA$, respectively. The closest $\mathrm{H}$. . . Na distance would be $\mathrm{H}(1) \ldots \mathrm{Na}(2)=2.39 \AA$.

Collection of the diffractometer data was made possible through the cooperation of E. C. Prince. The x-ray 67 system of computing programs (J. M. Stewart, University of Maryland, Editor) was used for most calculations. We thank Joy S. Bowen and Pamela B. Kingsbury for technical help.

This investigation was supported in part by research grant DE-00572-09 to the American Dental Association from the National Institute of Dental Research and is part of the dental research program conducted by the National Bureau of Standards, in cooperation with 
the Council on Dental Research of the American Dental Association; the United States Army Medical Research and Development Command; the Dental Sciences Division of the School of Aerospace Medicine, USAF; the National Institute of Dental Research; and the Veterans Administration.

\section{References}

[1] Harper, J. P., Crystal structure of sodium carbonate monohydrate, $\mathrm{Na}_{2} \mathrm{CO}_{3} \cdot \mathrm{H}_{2} \mathrm{O}, \mathrm{Z}$. Krist. 95, 266-273 (1936).

[2] Dickens, B., and Brown, W. E., The crystal structures of $\mathrm{CaNa}_{2}\left(\mathrm{CO}_{3}\right)_{2} \cdot 5 \mathrm{H}_{2} \mathrm{O}$, synthetic gaylussite, and $\mathrm{CaNa}_{2}\left(\mathrm{CO}_{3}\right)_{2}$ $\cdot 2 \mathrm{H}_{2} \mathrm{O}$, synthetic pirssonite, Inorg. Chem. 8, 2093-2103 (1969).

[3] Brown, W. E., Crystal structure of octacalcium phosphate; Nature 196, 1048-1050 (1962).

[4] Brown, C. J., Peiser, H. S., and Turner-Jones, A., The crystal of sodium sesquicarbonate, Acta Cryst. 2, 167-174 (1949).

[5] Bacon, G. E., and Curry, N. A., A neutron-diffraction study of sodium sesquicarbonate, Acta Cryst. 2, 82-85 (1956).

[6] Candlin, R., Thermal changes in the structure of sodium sesquicarbonate, Acta Cryst. 9, 545-554 (1956).

[7] Pabst, A., On the hydrates of sodium carbonate, Amer. Min. 15, 69-73 (1930).
[8] Reimann, C. W., Mighell, A. D., and Mauer, F. A., The crystal and molecular structure of tetra isopyrazole-nickel chloride, $\mathrm{Ni}\left(\mathrm{C}_{3} \mathrm{H}_{4} \mathrm{~N}_{2}\right)_{4} \mathrm{Cl}_{2}$, Acta Cryst. 23, 135-141 (1967).

[9] Mauer, F. A., and Koenig, A. L., An automatic diffractometer for off-line operation, American Crystallographic Association, Summer Meeting, Abstract E10, University of Minnesota, Minneapolis, Minn. Aug. 20-25, (1967).

[10] International Tables for X-ray Crystallography 3, p. 202 (The Kynoch Press, Birmingham, England, 1962).

[11] McWeeney, R., x-ray scattering by aggregates of bonded atoms. I. Analytical approximations in single-atom scattering, Acta Cryst. 4, 513-519 (1951).

[12] Chastain, R. V., An algorithm for finding a set of phases directly from sigma two relationships, In, x-ray 67-Program System for x-ray Crystallography, Technical Report 67-58, Ed. J. M. Stewart, pp 71-75, University of Maryland, College Park, Md. (1967).

[13] Palache, C., Berman, H., and Frondel, C., Thermonatrite $\left[\mathrm{Na}_{2} \mathrm{CO}_{3} \cdot \mathrm{H}_{2} \mathrm{O}\right]$, The System of Mineralogy of J. D. Dana and E. S. Dana, 7th ed., 2, p. 224 (J. Wiley and Sons, New York, N.Y., 1951).

[14] Winchell, A. N., and Winchell, H., The Microscopical Characters of Artifical Inorganic Solid Substances: Optical Properties of Artifical Minerals (Academic Press, New York, 1964).

[15] Wells, A. F., Structural Inorganic Chemistry, 3rd ed. p. 587 (Oxford University Press, London, 1962).

(Paper 74.A3-603) 